\title{
New Insights into the Discovery of Novel Drugs to Treat Human Pulmonary Adenocarcinoma
}

\author{
Yu Wang1, Haishan Zhang2, Yingxin Chen ${ }^{3}$, Lining Wang1* \\ ${ }^{1}$ Department of Laboratory, Central Hospital Affiliated to Shenyang Medical College, Shenyang, China \\ ${ }^{2}$ Department of Cardiology, The First Hospital of China Medical University, Shenyang, China \\ ${ }^{3}$ Department of Ophthalmology, The General Hospital of Shenyang Military Area Command, Shenyang, China \\ Email: 18002477193@163.com, zhanghaishan99@sohu.com, cyx156@163.com, *w111111jp@hotmail.com
}

How to cite this paper: Wang, Y., Zhang, H.S., Chen, Y.X. and Wang, L.N. (2019) New Insights into the Discovery of Novel Drugs to Treat Human Pulmonary Adenocarcinoma. Journal of Cancer Therapy, 10, 178-187.

https://doi.org/10.4236/jct.2019.102014

Received: February 1, 2019

Accepted: February 18, 2019

Published: February 21, 2019

Copyright $\odot 2019$ by author(s) and Scientific Research Publishing Inc. This work is licensed under the Creative Commons Attribution International License (CC BY 4.0).

http://creativecommons.org/licenses/by/4.0/

\begin{abstract}
Lung cancer is one of the most prevalent cancers in the world. A cisplatin-based chemotherapy regimen is commonly used to major patients who have adenocarcinoma. Because of the limited remission rate, many patients need receive second-line treatment after receiving first-line chemotherapy. Drug screenings carried out currently are mainly from single phase. In consideration of systemic treatment, evaluation of a novel drug candidate from the point of view of first-line and second-line treatment is supposed to be important in the process of drug screening. In this review, we propose a flow of searching for new drugs, which is tailored to accommodate to first-line and second-line treatment in clinic.
\end{abstract}

\section{Keywords}

Cisplatin, Docetaxel, Pemetrexed, Adenocarcinoma, In Vitro, In Vivo, Clinical Trial

\section{Introduction}

Non-small cell lung cancer (NSCLC) is about $75 \%-80 \%$ of the primary lung cancers. Many patients need secondary chemotherapy after receiving first-line treatment due to the limited remission rate [1] [2] [3] [4]. Researchers are making great efforts to search for more effective drugs. Traditionally, the first-line chemotherapy is cisplatin based regimen, including another third generation drug, such as docetaxel, paclitaxel and gemcitabine [5] [6] [7]. For the second-line treatment, pemetrexed and docetaxel are constantly used [1] [2] [3] [8] [9]. The relationship between histology and first-line regimen has been realized in recent years; there are reports indicating that pemetrexed is suitable to be used for 
nonsquamous histology which can give a better OS, while not for squamous histology [3] [10] [11]. Based on these reports, previously we designed an experiment to see the effect when human adenocarcinoma A549 cells received first-line and second-line treatment in vitro [12]. We analyzed the inhibiting effect of cell proliferation from the group by adding docetaxel following treatment with cisplatin and pemetrexed (Pem-Doc group) and compared with that from another group in which pemetrexed was added subsequent to treatment with cisplatin and docetaxel (Doc-Pem group). Pem-Doc group showed an increased inhibiting effect of cell proliferation. Concerning cisplatin resistance gene excision repair crosscompletion gene1 (ERCC1) [13] [14], the gene expression and protein levels of ERCC1 in the Pem-Doc group were decreased. Interestingly, results from this treatment model are consistent with clinical findings. This makes it possible to evaluate new drug candidate taking first-line and second-line effect into account. Therefore, the first-line and second-line treatment model could be thought as an appropriate step for screening of drugs for first-line and second-line treatment in clinic. Here, we propose a flow of searching for new drugs that is suitable for first-line and second-line treatment in clinic (Table 1).

\section{Sources}

Sources for screening include chemical compounds, natural products (plants, marine organisms), peptides, antibodies etc. [15] [16] [17] [18]. Compounds used as chemotherapy drugs mainly come from natural plants or from synthesized compounds and their derivatives. Chemical synthesis remains an important method providing compounds. Traditionally, compounds were synthesized by trial-and-error method, with the advent of combinatorial chemistry, available compounds increased dramatically. For example, 44,000 compounds were screened with the result that a novel small molecule compound (iMDK) could be a potential therapeutic approach for the treatment of lung cancers that are driven by MDK [19]. Similarly, plant-derived anticancer drugs have a long history of use in cancer treatment. Paclitaxel, the most excellent anticancer drug discovered in recent years was isolated from the leaves of various taxus species. Paclitaxel promotes microtubule polymerization and inhibits depolymerization, which results in the death of cancer cells. Docetaxel, an analogue of paclitaxel, is widely used to treat many kinds of cancers including NSCLC [5] [6] [7]. Marine organisms constitute a rich source with the feature of structural diversity and extremely potent biological activeness. For instance, tunicate-derived ET-743 is a marine natural product which was approved in Europe as an antitumor agent [20]. Peptide library is also a good source of targeted ligands [21]. By screening a random cyclic peptide phage display library, a cyclic peptide CIGB-300 was found to exhibit anticancer properties and seems to have synergistic effect when used with chemotherapeutic agents together for lung cancer [22]. Due to small sizes, peptides can be synthesized in large quantities, with high affinities for protein receptors which make them more attractive. Antibody library is another 
Table 1. Recommended flow of searching for new drugs.

\begin{tabular}{|c|c|c|}
\hline Stage & $\begin{array}{l}\text { Sources: chemical compounds; natural products (plants, } \\
\text { marine organisms); peptides; antibodies }\end{array}$ & \\
\hline In vitro & $\begin{array}{l}\text { Methods: high throughput screening (HTS), high content } \\
\text { screening (HCS), surface plasmon resonance (SPR) } \\
\text { biosensor, yeast two hybrid }\end{array}$ & $\begin{array}{l}\text { Minimizing } \\
\text { candidates }\end{array}$ \\
\hline In vivo/Ex vivo & $\begin{array}{l}\text { Animal models: } \\
\text { wild type } \\
\text { transgenic/knockout } \\
\text { xenograft models: } \\
\text { in vivo study (cultured cancer cells): } \\
\text { subcutaneously, orthotopically, systemically } \\
\text { ex vivo study (cancer tissues from patients surgically): } \\
\text { subcutaneously, orthotopically }\end{array}$ & $\begin{array}{l}\text { Analyzing } \\
\text { pharmacokinetics, } \\
\text { effect and toxic side } \\
\text { effect }\end{array}$ \\
\hline Super vitro & $\begin{array}{l}\text { First-line second-line treatment model } \\
\text { with pemetrexed-docetaxel as standard control }\end{array}$ & $\begin{array}{l}\text { Accommodating } \\
\text { to first-line and } \\
\text { second-line } \\
\text { treatment in clinic }\end{array}$ \\
\hline In vivo & $\begin{array}{l}\text { Clinical trials } \\
\text { Phase I: safety and dosage } \\
\text { Phase II: efficacy and side effects } \\
\text { Phase III: efficacy and monitoring of adverse reactions } \\
\text { Phase IV: safety and efficacy }\end{array}$ & \\
\hline
\end{tabular}

good choice for screening because of high biological activities. Epidermal growth factor receptor (EGFR), a member of the ErbB family, is commonly over expressed in several cancers including NSCLC. Due to inverse correlation with prognosis, EGFR has been studied and proved to be a molecular target for NSCLC treatment. Necitumumab, which is a monoclonal antibody screened by a monoclonal antibody library, can bind the extracellular domain of EGFR and block EGF signal pathway [23]. Necitumumab was proved to be effective and approved to be used for treating squamous lung cancer by FDA [24].

\section{In Vitro Stage}

Several commonly used screening techniques include high throughput screening (HTS), high content screening (HCS), surface plasmon resonance (SPR), yeast two hybrid et al. HTS is the process to study the effects of large numbers of samples on the biological activity of targets such as proteins, enzymes, ion channels, receptors [25] [26]. According to the status of targets, HTS assays could be divided into cell-free assay or cell-based assay in which target resides in the cell. Also HTS could be divided into radiometric assay or fluorescence-based assay. For example, 2802 compounds were tested by a cell-based fluorescence assay with the result that aclacinomycin can reduce EGFR levels and radiosensitize EGFR-mutant non-small cell lung cancer [27]. Comparing with the simplicity of 
HTS which only observes one parameter, HCS can detect multiple parameters including cellular and subcellular phenotypes, cellular image readout, morphology analysis, cell counting etc. [28]. In an image-based HCS, 1280 pharmacologically active compounds were screened with a consequent that identifying twelve potent high drug-efflux cancer cells (HDECC) inhibitors, which may potentially be used as potential adjuvant to improve the efficacy of chemotherapeutic drugs [29]. Furthermore some researchers developed modified screening by adding new methods. For instance, a high content clonogenic survival drug screen identifies MEK inhibitors as potent radiation sensitizers for KRAS mutant non-small cell lung cancer [30]. Surface plasmon resonance (SPR) biosensor is the method to detect the interaction between low molecular weight fragment of compounds and membrane protein drug targets, such as G-protein coupled receptors (GPCRs) [31] [32]. In contrast to conventional high-throughput screening, SPR is suitable to screen compounds with low molecular weight because low affinities can be detected. Yeast two hybrid is a method to detect the interaction between two proteins in living cells. As the protein-protein interactions are promising drug targets, are being studied by many researches in the field of drug screening [33].

\section{In Vivo/Ex Vivo Stage}

Animals are used to study the pharmacokinetics, effect and toxic side effect of candidate compound since long time ago. In recent years, transgenic/knockout mice are used to analyze gene function, protein function, chemotherapy effect et al. For instance, transgenic mice expressing activated EGFR invariably developed multifocal lung adenocarcinomas [34]. Similarly, IL-6 deficient mice developed much more lung tumors after an activating mutant of K-Ras was induced in the lungs comparing with wild type mice [35]. Xenograft models are created by injecting human cancer cells into immunocompromised mice, subcutaneously, orthotopically, or systemically [36] [37] [38]. Xenograft models are primarily used to examine chemotherapy effect in vivo. EX vivo models are created by grafting cancer tissues into the immunocompromised mice subcutaneously or orthotopically immediately after surgeries [39] [40] [41]. With these murine models, more information about therapeutic effect and molecular mechanism of novel drug can be got and lead to further research.

\section{Super Vitro Stage}

Drug screenings carried out currently are mainly by studying effect during single phase. However, second-line even third-line treatment is common in clinic. To get better therapeutic effect for an individual patient, possible second-line treatment following first-line should be considered. Estimating new drug candidate taking first-line second-line effect into account becomes necessary. Previously we designed an experiment to simulate first-line and second-line treatment in clinic [12], which compared inhibiting effect of cancer cell proliferation from the group by adding docetaxel following treatment with cisplatin and pemetrexed 
(Pem-Doc group) with that from another group in which pemetrexed was added subsequent to treatment with cisplatin and docetaxel (Doc-Pem group). Pem-Doc group showed an increased inhibiting effect of cell proliferation which is consistent with results from clinical trials. Thus Pem-Doc group can be used as a control in case of cisplatin-based chemotherapy regimen. Therefore, we recommend to use this first-line and second-line treatment model as a good step to screen drugs for first-line and second-line treatment in clinic as it reflects better than traditional single phase. In the super vitro stage, as shown in Table 2, new candidate can be combined with cisplatin in first-line treatment followed by docetaxel in second-line treatment or be added in second-line treatment following treatment with cisplatin and pemetrexed in first-line treatment. This experiment will help us to determine if candidate is suitable for first-line treatment or second-line treatment, respectively. Also we can test effects of two candidates (A, B) simultaneously as shown in Table 2. For those with better cell proliferation assay (CPA) results, candidates could be studied further to see the gene and protein expression of ERCC1 by using Real-Time PCR and western blots.

\section{In Vivo Stage}

Clinical trials are divided into 4 phases (Phases I, II, III, and IV). In Phase I, 20 to 100 healthy volunteers or people with pulmonary adenocarcinoma participate with a period of several months. In Phase II, up to several hundred people with pulmonary adenocarcinoma participate with a period of several months to 2 years. In Phase III, 300 to 3000 volunteers who have pulmonary adenocarcinoma participate with a period of 1 to 4 years. In Phase IV, several thousand volunteers who have pulmonary adenocarcinoma participate.

\section{Conclusion}

Pulmonary adenocarcinoma is about $50 \%$ of the NSCLC. How to increase chemotherapy effect remains to be a problem both in clinic treatment and in the field of research. A cisplatin-based chemotherapy regimen has been the main solution for treating advanced NSCLC. Docetaxel and pemetrexed are two commonly used drugs, which have shown stable effects on many treatments. With further study, some mutations in case of adenocarcinoma were discovered including KRAS, EGFR, BRAF, HER2 etc. [42]. This led to the discovery of novel target EGFR-TKI drugs, such as erlotinib and gefitinib, which could inhibit proliferation of cancer cells through impairing EGFR kinase activating [43]. These EGFR-TKI drugs execute effects on condition that there are EGFR mutations. Reports indicated that EGFR mutations were found in about $16.6 \%$ of total Caucasian lung adenocarcinoma patients. It is thought that about $15 \%$ of patients with adenocarcinoma of the lung are ideal candidates for these targeted therapies [43] [44]. Recently, a report indicated that EGFR mutations were found in about $50.2 \%$ of patients of mainland China [45]. Samples can be used to detect EGFR mutations which include tumor tissues from surgery or needle biopsy, peripheral blood and pleural fluid. A report indicated that concordance 
Table 2. Recommended flow of super vitro study.

\begin{tabular}{ccccc}
\hline & Standard control & Candidate A & Candidate A & Candidate A, B \\
\hline First-line & Pem + DDP & A + DDP & Pem + DDP & A + DDP \\
Second-line & Doc & Doc & A & B \\
& CPA & CPA & CPA & CPA \\
\hline
\end{tabular}

Doc: docetaxel; Pem: pemetrexed; DDP: cisplatin; CPA: Cell proliferation assay.

rate in EGFR mutation detection between peripheral blood and tumor tissue was about $85.1 \%$ [46]. Detection from tissue is thought to be the most accurate, but it fits patients with surgeries or biopsies. Nevertheless, there are primary resistance and acquired resistance to EGFR-TKI therapy [47]. There is another kind of target drug monoclonal antibodies, which can block the signal transmission by combining with relevant receptors. Currently, there are monoclonal antibodies against EGFR (necitumumab for squamous cancer) or against VEGFR (ramucirumab) [48] [49]. Ramucirumab can be used to treat non-squamous NSCLC in combination with standard chemotherapy [49] [50]. Therefore, cisplatin-based chemotherapy regimen still is the main solution to major patients who have adenocarcinoma. In this review, we proposed that a flow probably could be used for screening for novel drugs fitting first-line and second-line treatment in clinic.

\section{Funding}

The present study was supported by a grant from Shenyang Medical College for the Returned Overseas Chinese Scholars of Lining Wang (No. 20144062).

\section{Conflicts of Interest}

The authors declare no conflicts of interest regarding the publication of this paper.

\section{References}

[1] Hanna, N., Shepherd, F.A., Fossella, F.V., Pereira, J.R., De Marinis, F., von Pawel, J., et al. (2004) Randomized Phase III Trial of Pemetrexed versus Doeetaxel in Patients with Non-Small-Cell Lung Cancer Previously Treated with Chemotherapy. Journal of Clinical Oncology, 22, 1589-1597.

https://doi.org/10.1200/JCO.2004.08.163

[2] Di Maio, M., Perrone, F., Chiodini, P., Gallo, C., Camps, C., Schuette, W., et al. (2007) Individual Patient Data Meta-Analysis of Docetaxel Administered Once Every 3 Weeks Compared with Once Every Week Second-Line Treatment of Advancednon-Small-cell Lung Cancer. Journal of Clinical Oncology, 25, 1377-1382. https://doi.org/10.1200/JCO.2006.09.8251

[3] Peterson, P., Park, K., Fossella, F., Gatzemeier, U., John, W. and Scagliotti, G.V. (2007) Is Pemetrexed More Effective in Adenocarcinoma and Large Cell Lung Cancer than in Squamous Cell Carcinoma? A Retrospective Analysis of a Phase III Trial of Pemetrexed vs. Docetaxel in Previously Treated Patients with Advanced Non-Small Cell Lung Cancer (NSCLC). Journal of Thoracic Oncology, 2, s851. https://doi.org/10.1097/01.JTO.0000284677.33344.62 
[4] Al-Farsi, A. and Ellis, P.M. (2014) Treatment Paradigms for Patients with Metastatic Non-Small Cell Lung Cancer, Squamous Lung Cancer: First, Second, and Third-Line. Frontiersin Oncology, 4, 157. https://doi.org/10.3389/fonc.2014.00157

[5] Gatzemeier, U., von Pawel, J., Gottfried, M., ten Velde, G.P., Mattson, K., de Marinis, F., et al. (2000) Phase III Comparative Study of High-Dose Cisplatin versus a Combination of Paclitaxel and Cisplatin in Patients with Advanced Non-Small Cell Lung Cancer. Journal of Clinical Oncology, 18, 3390-3399.

https://doi.org/10.1200/JCO.2000.18.19.3390

[6] Scagliotti, G.V., De Marinis, F., Rinaldi, M., Crino, L., Gridelli, C., Ricci, S., et al. (2002) Italian Lung Cancer Project: Phase III Randomized Trial Comparing Three Platinum-Based Doublets in Advanced Non-Small-Cell Lung Cancer. Journal of Clinical Oncology, 20, 4285-4291. https://doi.org/10.1200/JCO.2002.02.068

[7] Schiller, J.H., Harrington, D., Belani, C.P., Langer, C., Sandler, A., Krook, J., et al. (2002) Comparison of Four Chemotherapy Regimens for Advanced Non-Small-Cell Lung Cancer. The New England Journal of Medicine, 346, 92-98. https://doi.org/10.1056/NEJMoa011954

[8] Shepherd, F.A., Dancey, J., Ramlau, R., Mattson, K., Gralla, R., O’Rourke, M., et al. (2000) Prospective Randomized Trial of Docetaxel versus Best Supportive Care in Patients with Non-Small-Cell Lung Cancer Previously Treated with Platinum Based Chemotherapy. Journal of Clinical Oncology, 18, 2095-2103.

https://doi.org/10.1200/JCO.2000.18.10.2095

[9] Fossella, F.V., DeVore, R., Kerr, R.N., Crawford, J., Natale, R.R., Dunphy, F., et al. (2000) Randomized Phase III Trial of Docetaxel versus Vinorelbine or Ifosfamide in Patients with Advanced Non-Small-Cell Lung Cancer Previously Treated with Platinum-Containing Chemotherapy Regimens. The TAX 320 Non-Small Cell Lung Cancer Study Group. Journal of Clinical Oncology, 18, 2354-2362. https://doi.org/10.1200/JCO.2000.18.12.2354

[10] Scagliotti, G.V., Parikh, P., von Pawel, J., Biesma, B., Vansteenkiste, J., Manegold, C., et al. (2008) Phase III Study Comparing Cisplatin plus Gemcitabine with Cisplatin plus Pemetrexed in Chemotherapy-Naive Patients with Advanced-Stage Nonsmall-Cell Lung Cancer. Journal of Clinical Oncology, 26, 3543-3551. https://doi.org/10.1200/JCO.2007.15.0375

[11] Scagliotti, G., Hanna, N., Fossella, F., Sugarman, K., Blatter, J., Peterson, P., et al. (2009) The Differential Efficacy of Pemetrexed According to NSCLC Histology: A Review of Two Phase III Studies. Oncologist, 14, 253-263. https://doi.org/10.1634/theoncologist.2008-0232

[12] Wang, L.N., Wang, Y., Guan, Q., Liu, Y., He, T.Y. and Wang, J.R. (2016) Establishment of a first-line second-line Treatment Model for Human Pulmonary Adenocarcinoma. Oncology Letters, 12, 4461-4466. https://doi.org/10.3892/ol.2016.5299

[13] Liu, Y.-P., Ling, Y., Qi, Q.-F., Zhang, Y.-P., Zhang, C.-S., Zhu, C.-T., et al. (2013) The Effects of ERCC1 Expression Levels on the Chemosensitivity of Gastric Cancer Cells to Platinum Agents and Survival in Gastric Cancer Patients Treated with Oxaliplatin-Based Adjuvant Chemotherapy. Oncology Letters, 5, 935-942. https://doi.org/10.3892/ol.2012.1096

[14] Cai, Y., Yan, X., Zhang, G.Q., Zhao, W.H. and Jiao, S.C. (2015) The Predictive Value of ERCC1 and p53 for the Effect of Panobinostat and Cisplatin Combination Treatment in NSCLC. Oncotarget, 6, 18997-19005. https://doi.org/10.18632/oncotarget.3620

[15] Huggins, D.J., Venkitaraman, A.R. and Spring, D.R. (2011) Rational Methods for the Selection of Diverse Screening Compounds. ACS Chemical Biology, 6, 208-217. 
https://doi.org/10.1021/cb100420r

[16] Cragg, G.M. and Newman, D.J. (2013) Natural Products: A Continuing Source of Novel Drug Leads. Biochimica et Biophysica Acta, 1830, 3670-3695.

https://doi.org/10.1016/j.bbagen.2013.02.008

[17] Kennedy, J.P., Williams, L., Bridges, T.M., Daniels, R.N., Weaver, D. and Lindsley, C.W. (2008) Application of Combinatorial Chemistry Science on Modern Drug Discovery. Journal of Combinatorial Chemistry, 10, 345-354. https://doi.org/10.1021/cc700187t

[18] Corbi-Verge, C. and Kim, P.M. (2016) Motif Mediated Protein-Protein Interactions as Drug Targets. Cell Communication and Signaling, 14, 8. https://doi.org/10.1186/s12964-016-0131-4

[19] Hao, H., Maeda, Y., Fukazawa, T., Yamatsuji, T., Takaoka, M., Bao, X.H., et al. (2013) Inhibition of the Growth Factor MDK/Midkine by a Novel Small Molecule Compound to Treat Non-Small Cell Lung Cancer. PLoS ONE, 8, e71093. https://doi.org/10.1371/journal.pone.0071093

[20] Newman, D.J. and Cragg, G.M. (2004) Marine Natural Products and Related Compounds in Clinical and Advanced Preclinical Trials. Journal of Natural Products, 67, 1216-1238. https://doi.org/10.1021/np040031y

[21] Tavassoli, A. (2017) SICLOPPS Cyclic Peptide Libraries in Drug Discovery. Current Opinion in Chemical Biology, 38, 30-35. https://doi.org/10.1016/j.cbpa.2017.02.016

[22] Perera, Y., Toro, N.D., Gorovaya, L., Fernandez-DE-Cossio, J., Farina, H.G. and Perea, S.E. (2014) Synergistic Interactions of the Anti-Casein Kinase 2 CIGB-300 Peptide and Chemotherapeutic Agents in Lung and Cervical Preclinical Cancer Models. Molecular and Clinical Oncology, 2, 935-944. https://doi.org/10.3892/mco.2014.338

[23] Dantas-Barbosa, C., de Macedo Brigido, M. and Maranhao, A.Q. (2012) Antibody Phage Display Libraries: Contributions to Oncology. International Journal of Molecular Sciences, 13, 5420-5240. https://doi.org/10.3390/ijms13055420

[24] Thatcher, N., Hirsch, F.R., Luft, A.V., Szczesna, A., Ciuleanu, T.E., Dediu, M., et al. (2015) Necitumumab plus Gemcitabine and Cisplatin versus Gemcitabine and Cisplatin Alone as First-Line Therapy in Patients with Stage IV Squamous Non-Small-Cell Lung Cancer (SQUIRE): An Open-Label, Randomised, Controlled Phase 3 Trial. Lancet Oncology, 16, 763-774. https://doi.org/10.1016/S1470-2045(15)00021-2

[25] Sittampalam, G.S., Kahl, S.D. and Janzen, W.P. (1997) High-Throughput Screening: Advances in Assay Technologies. Current Opinion in Chemical Biology, 1, 384-391. https://doi.org/10.1016/S1367-5931(97)80078-6

[26] Silverman, L., Campbell, R. and Broach, J.R. (1998) New Assay Technologies for High-Throughput Screening. Current Opinion in Chemical Biology, 2, 397-403. https://doi.org/10.1016/S1367-5931(98)80015-X

[27] Bennett, D.C., Charest, J., Sebolt, K., Lehrman, M., Rehemtulla, A. and Contessa, J.N. (2013) High-Throughput Screening Identifies Aclacinomycin as a Radiosensitizer of EGFR-Mutant Non-Small Cell Lung Cancer. Translational Oncology, 6, 382-391. https://doi.org/10.1593/tlo.13232

[28] Singh, S., Carpenter, A.E. and Genovesio, A. (2014) Increasing the Content of High-Content Screening: An Overview. Journal of Biomolecular Screening, 19, 640-650. https://doi.org/10.1177/1087057114528537

[29] Xia, X., Yang, J., Li, F., Li, Y., Zhou, X., Dai, Y., et al. (2010) Image-Based Chemical Screening Identifies Drug Efflux Inhibitors in Lung Cancer Cells. Cancer Research, 70, 7723-7733. https://doi.org/10.1158/0008-5472.CAN-09-4360 
[30] Lin, S.H., Zhang, J., Giri, U., Stephan, C., Sobieski, M., Zhong, L., et al. (2014) A High Content Clonogenic Survival Drug Screen Identifies Mek Inhibitors as Potent Radiation Sensitizers for KRAS Mutant Non-Small-Cell Lung Cancer. Journal of Thoracic Oncology, 9, 965-973. https://doi.org/10.1097/JTO.0000000000000199

[31] Shepherd, C.A., Hopkins, A.L. and Navratilova, I. (2014) Fragment Screening by SPR and Advanced Application to GPCRs. Progress in Biophysics \& Molecular Biology, 116, 113-123. https://doi.org/10.1016/j.pbiomolbio.2014.09.008

[32] Nguyen, H.H., Park, J., Kang, S. and Kim, M. (2015) Surface Plasmon Resonance: A Versatile Technique for Biosensor Applications. Sensors, 15, 10481-10510. https://doi.org/10.3390/s150510481

[33] Blangy, A. and Fort, P. (2012) Using a Modified Yeast Two-Hybrid System to Screen for Chemical GEF Inhibitors. Methods in Molecular Biology, 928, 81-95. https://doi.org/10.1007/978-1-62703-008-3_7

[34] Ohashi, K., Rai, K., Fujiwara, Y., Osawa, M., Hirano, S., Takata, K., et al. (2008) Induction of Lung Adenocarcinoma in Transgenic Mice Expressing Activated EGFR Driven by the SP-C Promoter. Cancer Science, 99, 1747-1753. https://doi.org/10.1111/j.1349-7006.2008.00875.x

[35] Qu, Z., Sun, F., Zhou, J., Li, L., Shapiro, S.D. and Xiao, G. (2015) Interleukin-6 Prevents the Initiation But Enhances the Progression of Lung Cancer. Cancer Research, 75, 3209-3215. https://doi.org/10.1158/0008-5472.CAN-14-3042

[36] Memon, A.A., Jakobsen, S., Dagnaes-Hansen, F., Sorensen, B.S., Keiding, S. and Nexo, E. (2009) Positron Emission Tomography (PET) Imaging with [11C]-Labeled Erlotinib: A Micro-PET Study on Mice with Lung Tumor Xenografts. Cancer Research, 69, 873-878. https://doi.org/10.1158/0008-5472.CAN-08-3118

[37] Steiner, P., Joynes, C., Bassi, R., Wang, S., Tonra, J.R., Hadari, Y.R., et al. (2007) Tumor Growth Inhibition with Cetuximab and Chemotherapy in Non-Small Cell Lung Cancer Xenografts Expressing Wild-Type and Mutated Epidermal Growth Factor Receptor. Clinical Cancer Research, 13, 1540-1551. https://doi.org/10.1158/1078-0432.CCR-06-1887

[38] Kellar, A., Egan, C. and Morris, D. (2015) Preclinical Murine Models for Lung Cancer: Clinical Trial Applications. Biomed Research International, 2015, Article ID: 621324. https://doi.org/10.1155/2015/621324

[39] Fichtner, I., Rolff, J., Soong, R., Hoffmann, J., Hammer, S., Sommer, A., et al. (2008) Establishment of Patient-Derived Non-Small Cell Lung Cancer Xenografts as Models for the Identification of Predictive Biomarkers. Clinical Cancer Research, 14, 6456-6468. https://doi.org/10.1158/1078-0432.CCR-08-0138

[40] Merk, J., Rolff, J., Becker, M., Leschber, G. and Fichtner, I. (2009) Patient-Derived Xenografts of Non-Small-Cell Lung Cancer: A Pre-Clinical Model to Evaluate Adjuvant Chemotherapy? European Journal of Cardiothoracic Surgery, 36, 454-459. https://doi.org/10.1016/j.ejcts.2009.03.054

[41] Dong, X., Guan, J., English, J.C., Flint, J., Yee, J., Evans, K., et al. (2010) Patient-Derived First Generation Xenografts of Non-Small Cell Lung Cancers: Promising Tools for Predicting Drug Responses for Personalized Chemotherapy. Clinical Cancer Research, 16, 1442-1451. https://doi.org/10.1158/1078-0432.CCR-09-2878

[42] Quéré, G., Descourt, R., Robinet, G., Autret, S., Raguenes, O., Fercot, B., et al. (2016) Mutational Status of Synchronous and Metachronous Tumor Samples in Patients with Metastatic Non-Small-Cell Lung Cancer. BMC Cancer, 16, 210. https://doi.org/10.1186/s12885-016-2249-6

[43] Roviello, G. (2015) The Distinctive Nature of Adenocarcinoma of the Lung. Onco- 
Targets and Therapy, 8, 2399-2406. https://doi.org/10.2147/OTT.S89225

[44] Rosell, R., Moran, T., Queralt, C., Porta, R., Cardenal, F., Camps, C., et al. (2009) Screening for Epidermal Growth Factor Receptor Mutations in Lung Cancer. New England Journal of Medicine, 361, 958-967.

https://doi.org/10.1056/NEJMoa0904554

[45] Shi, Y., Li, J., Zhang, S., Wang, M., Yang, S., Li, N., et al. (2015) Molecular Epidemiology of EGFR Mutations in Asian Patients with Advanced Non-Small-Cell Lung Cancer of Adenocarcinoma Histology Mainland China Subset Analysis of the PIONEER Study. PLoS ONE, 10, e0143515.

https://doi.org/10.1371/journal.pone.0143515

[46] Que, D., Xiao, H., Zhao, B., Zhang, X., Wang, Q., Xiao, H., et al. (2016) EGFR Mutation Status in Plasma and Tumor Tissues in Non-Small Cell Lung Cancer Serves as a Predictor of Response to EGFR-TKI Treatment. Cancer Biology \& Therapy, 17, 320-327. https://doi.org/10.1080/15384047.2016.1139238

[47] Cappuzzo, F., Jänne, P.A., Skokan, M., Finocchiaro, G., Rossi, E., Ligorio, C., et al. (2009) MET Increased Gene Copy Number and Primary Resistance to Gefitinib Therapy in Non-Small-Cell Lung Cancer Patients. Annals of Oncology, 20, 298-304. https://doi.org/10.1093/annonc/mdn635

[48] Presta, L.G., Chen, H., O’Connor, S.J., Chisholm, V., Meng, Y.G., Krummen, L., et al. (1997) Humanization of an Anti-Vascular Endothelial Growth Factor Monoclonal Antibody for the Therapy of Solid Tumors and Other Disorders. Cancer Research, 57, 4593-4599.

[49] Cooper, M.R., Binkowski, C., Hartung, J. and Towle, J. (2016) Profile of Ramucirumab in the Treatment of Metastatic Non-Small-Cell Lung Cancer. OncoTargets Therapy, 9, 1953-1960. https://doi.org/10.2147/OTT.S80239

[50] Johnson, D.H., Fehrenbacher, L., Novotny, W.F., Herbst, R.S., Nemunaitis, J.J., Jablons, D.M., et al. (2004) Randomized Phase II Trial Comparing Bevacizumab plus Carboplatin and Paclitaxel with Carboplatin and Paclitaxel Alone in Previously Untreated Locally Advanced or Metastatic Non-Small-Cell Lung Cancer. Journal of Clinical Oncology, 22, 2184-2191. https://doi.org/10.1200/JCO.2004.11.022 